\title{
New Hopane Triterpene from Eleocharis sellowiana (Cyperaceae)
}

\author{
Ana Lúcia T. G. Ruiz, ${ }^{*, a, b}$ Aderbal F. Magalhães, ${ }^{a}$ Aparecida D. Faria, ${ }^{c}$ Eva G. Magalhães ${ }^{a}$ \\ and Maria do Carmo E. Amaral ${ }^{c}$ \\ ${ }^{a}$ Instituto de Química, Universidade Estadual de Campinas, CP 6154, 13084-862 Campinas - SP, Brazil \\ ${ }^{b}$ Centro Pluridisciplinar de Pesquisas Químicas, Biológicas e Agrárias, Universidade Estadual de Campinas, \\ CP 6171, 13083-970 Campinas - SP, Brazil \\ ${ }^{c}$ Instituto de Biologia, Universidade Estadual de Campinas, CP 6109, 13083-970 Campinas - SP, Brazil
}

Do extrato hexânico de Eleocharis sellowiana foram isolados o novo triterpeno $3 \alpha$-hidroxi$13 \alpha, 17 \alpha, 21 \beta$-hopano-15,19-diona e hexadecanoato de $E$-fitila, caracterizados por dados de RMN e EM.

A new triterpene named $3 \alpha$-hydroxy-13 $\alpha, 17 \alpha, 21 \beta$-hopan-15,19-dione and E-phytyl hexadecanoate were isolated from the hexanic extract of Eleocharis sellowiana. NMR and MS experiments determined the molecular structures.

Keywords: Eleocharis, Cyperaceae, hopane-like triterpene

\section{Introduction}

The genus Eleocharis R. Br. (Cyperaceae, Cyperoideae, Scirpeae) includes about 200 species, occurring in wet environments like swamps, lakes and rivers margins. Their aerial parts are formed by simple, not ramified stalks that end in a spiciform inflorescence formed by numerous very inconspicuous flowers. Their subterraneous parts are formed by roots and stem (called rhizome or stolon, depending on its form). E. sellowiana Kunth occurs in Mexico, Colombia, Paraguay and Brazil. This species is widely distributed in São Paulo State. ${ }^{1}$ As many other plants from wet environments like swamps, lakes and rivers margins, Eleocharis species are subject of only a few studies. According to the literature ${ }^{2}$ only E. dulcis Trin., E. coloradoensis (Britt.) Gilly, E. acuta R. Br., E. microcarpa Torr. and E. smallii L. had been subjected to phytochemical analysis before.

In continuation of our phytochemical analysis of Eleocharis genus, ${ }^{3}$ the hexanic extracts of E. sellowiana (subterraneous and aerial parts) were subjected to a detailed chromatographic analysis resulting in the isolation of a new pentacyclic triterpene named $3 \alpha$-hydroxy$13 \alpha, 17 \alpha, 21 \beta$-hopan-15,19-dione (1) and $E$-phytyl hexadecanoate (2) (Figure 1).

*e-mail: aa_ruiz@hotmail.com.br

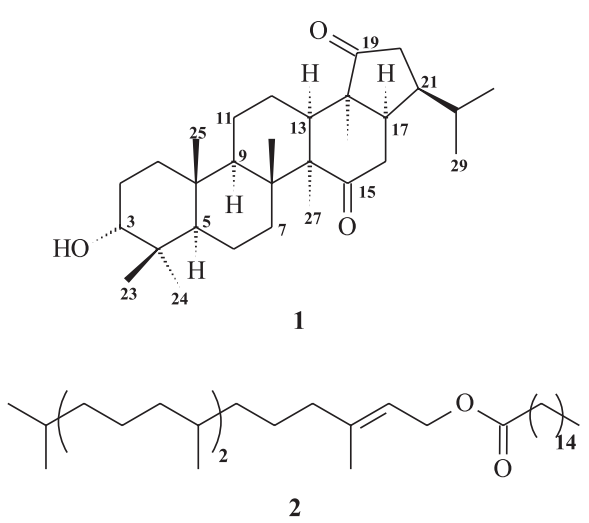

Figure 1. Compounds isolated from E. sellowiana.

\section{Results and Discussion}

Compound 1 was deduced as having an elemental formula of $\mathrm{C}_{30} \mathrm{H}_{48} \mathrm{O}_{3}$ by HREI-MS (observed $\mathrm{M}^{+*}=456.3607$; required $\left.\mathrm{M}^{+*}=456.3604\right)$. The presence of five signals as singlets $\left(\delta_{\mathrm{H}}\right.$ $0.85, \delta_{\mathrm{H}} 0.89, \delta_{\mathrm{H}} 0.94, \delta_{\mathrm{H}} 0.97$ and $\left.\delta_{\mathrm{H}} 1.15\right)$ and two signals as doublets $\left(\delta_{\mathrm{H}} 0.86, \mathrm{~d}, J 7.0 \mathrm{~Hz}, \mathrm{CH}_{3}-29\right.$, and $\delta_{\mathrm{H}} 1.00, \mathrm{~d}, J$ $7.0 \mathrm{~Hz}, \mathrm{CH}_{3}-30$ ) attributed to eight methyl groups in its ${ }^{1} \mathrm{H}$ NMR spectrum (Table 1) suggested a hopane-like or a lupanelike triterpene skeleton. The broad singlet at $\delta_{\mathrm{H}} 3.44$ (brs, $\mathrm{H}-3)$ together with the chemical shift of C-3 at $\delta_{\mathrm{C}} 75.9(\mathrm{CH})$ in its ${ }^{13} \mathrm{C}$ NMR spectrum (Table 2) suggested the presence of 
Table 1. ${ }^{1} \mathrm{H}$ NMR $\left(500 \mathrm{MHz}, \mathrm{CDCl}_{3}\right.$ ) and observed correlation in HSQC (vicinal C-H) and in $\mathrm{HMBC}$ (long-range C-H) spectra $\left(\mathrm{CDCl}{ }_{3}, 11 \mathrm{Tesla}\right)$ of $\mathbf{1}$

\begin{tabular}{cll}
\hline $\mathrm{H}(\delta)$ & $\mathrm{C}\left(\delta, J^{1}\right)$ & $\mathrm{C}\left(\delta, J^{\mathrm{n}}\right)$ \\
\hline $0.85(\mathrm{~s}, \mathrm{H}-26)$ & $16.8(\mathrm{C}-26)$ & $55.2(\mathrm{C}-14), 50.4(\mathrm{C}-9), 44.7(\mathrm{C}-8), 34.1(\mathrm{C}-7)$ \\
$0.85(\mathrm{~s}, \mathrm{H}-24)$ & $22.0(\mathrm{C}-24)$ & $75.9(\mathrm{C}-3), 48.8(\mathrm{C}-5), 37.4(\mathrm{C}-4), 28.2(\mathrm{C}-23)$ \\
$0.86(\mathrm{~d}, J$ J $7.0 \mathrm{~Hz}, \mathrm{H}-29)$ & $20.3(\mathrm{C}-29)$ & $48.9(\mathrm{C}-21), 28.9(\mathrm{C}-22), 22.4(\mathrm{C}-30)$ \\
$0.89(\mathrm{~s}, \mathrm{H}-25)$ & $16.3(\mathrm{C}-25)$ & $224.1(\mathrm{C}-19), 52.1(\mathrm{C}-18), 50.4(\mathrm{C}-17)$ \\
$0.94(\mathrm{~s}, \mathrm{H}-28)$ & $16.9(\mathrm{C}-28)$ & $75.9(\mathrm{C}-3), 48.8(\mathrm{C}-5), 37.4(\mathrm{C}-4), 22.0(\mathrm{C}-24)$ \\
$0.97(\mathrm{~s}, \mathrm{H}-23)$ & $28.2(\mathrm{C}-23)$ & $48.9(\mathrm{C}-21), 28.9(\mathrm{C}-22), 20.3(\mathrm{C}-29)$ \\
$1.00(\mathrm{~d}, J 7.0 \mathrm{~Hz}, \mathrm{H}-30)$ & $22.4(\mathrm{C}-30)$ & $215.7(\mathrm{C}-15), 55.2(\mathrm{C}-14), 44.7(\mathrm{C}-8)$ \\
$1.15(\mathrm{~s}, \mathrm{H}-27)$ & $18.1(\mathrm{C}-27)$ & $20.3(\mathrm{C}-29), 22.4(\mathrm{C}-30), 48.9(\mathrm{C}-21)$ \\
$1.76($ oct, $J 6.0 \mathrm{~Hz}, \mathrm{H}-22)$ & $28.9(\mathrm{C}-22)$ & $37.7(\mathrm{C}-8), 33.7(\mathrm{C}-1)$ \\
$1.87(\mathrm{~m}, \mathrm{H}-9)$ & $50.4(\mathrm{C}-9)$ & $52.1(\mathrm{C}-18), 22.4(\mathrm{C}-30), 20.3(\mathrm{C}-29)$ \\
$1.89(\mathrm{~m}, \mathrm{H}-17)$ & $50.4(\mathrm{C}-17)$ & $224.1(\mathrm{C}-19), 50.4(\mathrm{C}-17)$ \\
$1.91(\mathrm{q}, J 6.0 \mathrm{~Hz}, \mathrm{H}-21)$ & $48.9(\mathrm{C}-21)$ & $224.1(\mathrm{C}-19), 48.9(\mathrm{C}-21)$ \\
$2.18(\mathrm{~m}, \mathrm{H}-20)$ & $37.2(\mathrm{C}-20)$ & $215.7(\mathrm{C}-15)$ \\
$2.26(\mathrm{~m}, \mathrm{H}-20)$ & $37.2(\mathrm{C}-20)$ & $33.7(\mathrm{C}-1), 48.8(\mathrm{C}-5)$ \\
$2.55(\mathrm{~m}, \mathrm{H}-16)$ & $37.9(\mathrm{C}-16)$ & \\
$3.44(\mathrm{brs}, \mathrm{H}-3 \beta)$ & $75.9(\mathrm{C}-3)$ &
\end{tabular}

a $3 \alpha-\mathrm{OH}$ group ${ }^{4}$ (Table 2) while the signals in at $\delta_{\mathrm{C}} 215.7$ $(\mathrm{C}-15)$ and $\delta_{\mathrm{C}} 224.1(\mathrm{C}-19)$ showed correlation with the methyl hydrogens at $\mathrm{CH}_{3}-27$ e $\mathrm{CH}_{3}-28$ in the $\mathrm{HMBC} \mathrm{NMR}$ experiment (Table 1). These correlations indicated that both carbonyl carbons should not be present at C-ring. Analyzing the other correlations obtained in the HMBC NMR experiment, it was possible to determine the presence of the carbonyls at C-15 (D-ring) and at C-19 (E-ring) (Figure 2). The relative configuration at $\mathrm{C} / \mathrm{D}$ and at $\mathrm{D} / \mathrm{E}$ rings fusions was deduced through the valuable information about correlations among the hydrogen spin systems at carbons C16, C-20 and C-30 furnished by the 1D-TOCSY NMR experiment (Figure 3). Accordingly, when hydrogens H-20 were irradiated, it was possible to identify the hydrogens $\mathrm{H}$ 21 (q, $J 6.0 \mathrm{~Hz}$ ), H-22 (oct, $J 6.0 \mathrm{~Hz}$ ), H-29 (s) and H-30 (s). On the other hand, when the hydrogens $\mathrm{H}-16$ were irradiated, only the hydrogen H-17 was observed. The absence of polarization transference between $\mathrm{H}-17$ and $\mathrm{H}-21$ points out to a very small coupling constant between these hydrogens and consequently to a cis-D/E rings fusion with a $\beta$-isopropyl group. The C/D rings fusion should be a cis-fusion with the hydrogen $\mathrm{H}-13$ in a $\alpha$-position. Through the corresponding molecular model it is possible to see that the methyl group $\mathrm{CH}_{3}-26$ is under the $\mathrm{C}-19$ carbonyl protection cone, which explains the lower chemical shift of $\mathrm{CH}_{3}-26\left(\delta_{\mathrm{H}} 0.85\right)$ hydrogens when compared to those related for the $17 \alpha, 21 \beta$ hopane $\left(\delta_{\mathrm{H}} 0.95\right) .^{5}$ In its NOESY-1D spectrum, it was observed that when $\mathrm{CH}_{3}-27\left(\delta_{\mathrm{H}} 1.15\right)$ was irradiated increments were observed in $\mathrm{H}-7 \mathrm{a}\left(\delta_{\mathrm{H}} 1.72,1.78 \%\right), \mathrm{H}-9 \mathrm{a}$ $\left(\delta_{\mathrm{H}} 1.90,0.95 \%\right)$ and $\mathrm{H}-12 \mathrm{a}\left(\delta_{\mathrm{H}} 1.52,2.13 \%\right)$ but not in $\mathrm{CH}_{3}$ $28\left(\delta_{\mathrm{H}} 0.94\right)$. On the other hand, when $\mathrm{CH}_{3}-28\left(\delta_{\mathrm{H}} 0.94\right)$ was irradiated increments were just observed in $\mathrm{H}-22\left(\delta_{\mathrm{H}} 1.76\right.$, $1.66 \%$ ), corroborating with a $c i s-\mathrm{C} / \mathrm{D}$ rings fusion. In its HREIMS spectrum, there are some important fragment ions ${ }^{6}$

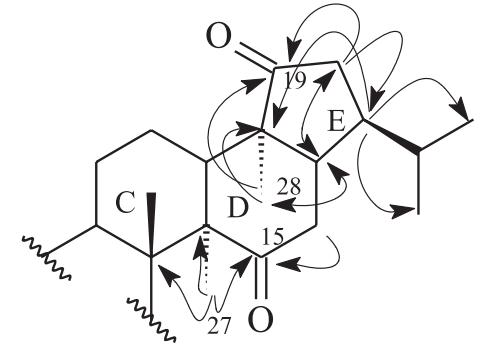

Figure 2. Observed correlation in HMBC (long-range C-H) spectra of $\mathbf{1}$.

that corroborated with the hydroxyl group at C-3 $(\mathrm{m} / z 207$, $16 \%, \mathbf{1 a}$ and $\mathrm{m} / \mathrm{z}, 189,100 \%, \mathbf{1 b})$ and with carbonyl groups location at D- and E-rings $(\mathrm{m} / \mathrm{z}, 318,85 \%, \mathbf{1 c} ; \mathrm{m} / \mathrm{z} 300,24 \%$, 1d; $m / z, 303,20 \%, \mathbf{1 e} ; m / z, 277,32 \%$, 1f) (Figure 4).

Compound $2\left(\mathrm{C}_{28} \mathrm{H}_{48} \mathrm{O}\right)$, isolated from the hexanic extract of E. sellowiana (aerial part), was identified as $E$ phytyl hexadecanoate by comparison of their ${ }^{1} \mathrm{H}$ and ${ }^{13} \mathrm{C}$ NMR and MS data with those previously published. ${ }^{7}$ The occurrence of compound $\mathbf{2}$ in the genus Eleocharis is described here for the first time.

\section{Experimental}

\section{General}

Thin layer chromatography (TLC): Silica gel $60 F_{254}$ $\mathrm{Al}$ sheets (Merck); detection at 254 and $365 \mathrm{~nm}$ and with anisaldehyde in acidic ethanol solution, ${ }^{8} \mathrm{CC}=$ column chromatography. ${ }^{1} \mathrm{H},{ }^{13} \mathrm{C}$ NMR and $2 \mathrm{D}$ experiments Varian Inova-500 (Palo Alto, CA, USA) spectrometer at 11 tesla. Chemical shifts of the compounds were recorded in $\mathrm{CDCl}_{3}$ solutions and were quoted relative to TMS for ${ }^{1} \mathrm{H}$ NMR $(\delta 0.0)$ and to $\mathrm{CDCl}_{3}(\delta 77.0)$ for ${ }^{13} \mathrm{C}$ NMR. Atributions: The triterpene numering (see Figure 1) is used in the results 
Table 2. ${ }^{13} \mathrm{C}$ NMR data of $\mathbf{1}$ and $\mathbf{3}$

\begin{tabular}{|c|c|c|}
\hline $\mathrm{C}$ & $\begin{array}{c}1 \\
\delta_{\mathrm{C}}{ }^{a}\end{array}$ & $\delta_{\mathrm{C}}{ }^{\mathrm{b}}$ \\
\hline $\mathrm{CH}_{2}-1$ & 33.7 & 33.2 \\
\hline $\mathrm{CH}_{2}-2$ & 25.3 & 25.3 \\
\hline $\mathrm{CH}-3$ & 75.9 & 76.2 \\
\hline C-4 & 37.4 & 37.5 \\
\hline CH-5 & 48.8 & 48.8 \\
\hline $\mathrm{CH}_{2}-6$ & 18.5 & 18.3 \\
\hline $\mathrm{CH}_{2}^{2}-7$ & 34.1 & 33.2 \\
\hline C-8 & 44.7 & 41.8 \\
\hline CH-9 & 50.4 & 50.0 \\
\hline C-10 & 37.8 & 37.2 \\
\hline $\mathrm{CH}_{2}-11$ & 21.9 & 20.9 \\
\hline $\mathrm{CH}_{2}-12$ & 24.5 & 24.1 \\
\hline $\mathrm{CH}-13$ & 50.4 & 49.9 \\
\hline C-14 & 55.2 & 41.9 \\
\hline C-15 & 215.7 & 34.7 \\
\hline $\mathrm{CH}_{2}-16$ & 37.9 & 21.9 \\
\hline $\mathrm{CH}-17$ & 50.4 & 53.9 \\
\hline C-18 & 52.1 & 44.1 \\
\hline C-19 & 224.1 & 41.3 \\
\hline $\mathrm{CH}_{2}-20$ & 37.2 & 26.6 \\
\hline $\mathrm{CH}-21$ & 48.9 & 51.1 \\
\hline $\mathrm{CH}-22$ & 28.9 & 73.9 \\
\hline $\mathrm{CH}_{3}-23$ & 28.2 & 28.3 \\
\hline $\mathrm{CH}_{3}^{3}-24$ & 22.0 & 22.1 \\
\hline $\mathrm{CH}_{3}^{3}-25$ & 16.3 & 15.7 \\
\hline $\mathrm{CH}_{3}^{3}-26$ & 16.8 & 17.0 \\
\hline $\mathrm{CH}_{3}^{3}-27$ & 18.1 & 17.1 \\
\hline $\mathrm{CH}_{3}-28$ & 16.9 & 16.2 \\
\hline $\mathrm{CH}_{3}-29$ & 20.3 & 28.7 \\
\hline $\mathrm{CH}_{3}-30$ & 22.4 & 30.9 \\
\hline
\end{tabular}

${ }^{\mathrm{a}} 125 \mathrm{MHz}, \mathrm{CDCl}_{3}$; ${ }^{\mathrm{b}}$ Tanaka and Matsunaga, reference 4.

and discussion and for spectroscopic data. HREIMS experiment: VG Auto Spec 10000 Micromass (Manchester, UK) instrument with an ionizing potencial of $70 \mathrm{eV}, \mathrm{m} / \mathrm{z}$ (rel. intensity in\%), direct probe.

\section{Plant material}

Samples of E. sellowiana were collected in Campinas, Brazil, and identified by two of the authors (A. D. F. and M. C. E. A.). Voucher specimens (A. D. Faria et al. 1000 - E. sellowiana) have been deposited in the Herbarium of the Botany Department of the Biology Institute of Unicamp (UEC), Campinas-SP, Brazil.

\section{Extraction}

The collected plant $($ Es $=$ E. sellowiana $)$ was separated into aerial (270.0g, EsA) and subterraneous (428.0g, EsS)

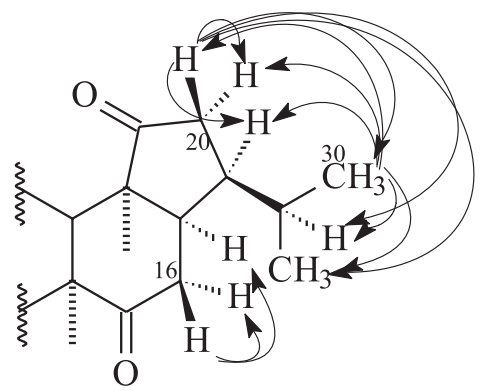

Figure 3. Observed correlation in 1D-TOCSY experiment of $\mathbf{1}$.

parts. Extracts of fresh subterraneous part were obtained by maceration with ethanol. The resultant extracts were combined, concentrated and diluted with $\mathrm{H}_{2} \mathrm{O}$ to get an aqueous EtOH solution, which was partitioned with hexane (EsSH, $358.4 \mathrm{mg}$ ) and $\mathrm{CHCl}_{3}$ (EsSC, $1303.4 \mathrm{mg}$ ); the respective aq. EtOH layers were then named EsSHE $(3010.0 \mathrm{mg}$ ). The air-dried milled aerial part (named EsA, $95.8 \mathrm{~g}$ ) was successively extracted in a Soxhlet apparatus with hexane (EsAH, $2249.3 \mathrm{mg}$ ), $\mathrm{CH}_{2} \mathrm{Cl}_{2}$ (EsAD, 447.9 $\mathrm{mg}$ ) and $\mathrm{MeOH}$ (EsAM, $3052.0 \mathrm{mg}$ ).

\section{Isolation}

Part of the hexanic extract EsSH $(300 \mathrm{mg}$ ) was subjected to flash CC over silica gel, ${ }^{8}$ eluted first with $\mathrm{CHCl}_{3}$-Hex (4:1). The eluent polarity was increased by the gradual addition of chloroform and then methanol until reaching $100 \%$ of methanol, furnishing 159 fractions (15

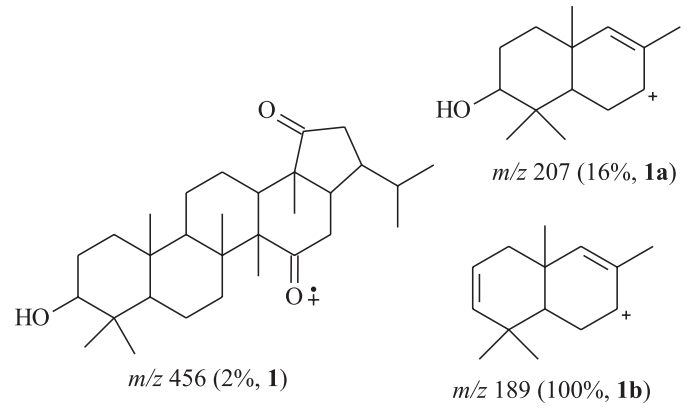<smiles>CC1(C)C(=[OH+])CCC2(C)C1CCC1(C)C2CCC(O)C1(C)C</smiles><smiles>CC1(C)C=CCC2(C)CCC3CC(=[OH+])C3(C)CCC12</smiles><smiles>CC12C(=O)CC1CCC1[C+]2CCC2C(C)(C)C(O)CCC12C</smiles>

$m / z 303(20 \%, \mathbf{1 e})$

Figure 4. Principal fragments observed in MS spectra of $\mathbf{1}$. 
$\mathrm{mL}$ ), which were reduced to 21 groups after TLC. Group 3 (29.4 mg, fractions 7 and 8), after successive preparative TLC run with $\mathrm{CHCl}_{3}-\mathrm{MeOH}(40: 1)$ and with $\mathrm{Et}_{2} \mathrm{O}-\mathrm{Hex}$ (2:1), afforded 1 (4.0 mg).

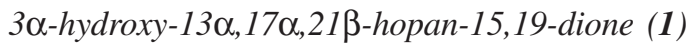

It was obtained as a colorless oil; ${ }^{1} \mathrm{H} \mathrm{NMR}\left(\mathrm{CDCl}_{3}\right.$, 500MHz): Table 2; ${ }^{13} \mathrm{C} \mathrm{NMR}\left(\mathrm{CDCl}_{3}, 125 \mathrm{MHz}\right)$ : Table 3; HREI-MS (70eV), m/z (\%): 456.3607 (2), 441.3680 (9), 318.2508 (85), 303.2231 (20), 300.2370 (24), 277.2109 (32), 233.1865 (12), 207.1671 (16), 189.1581 (100), 177.1566 (7), 175.1408 (38), 152.1162 (10), 139.1056 (17), 137.1275 (9), 135.1118 (62), 121.0952 (52), 109.0966 (41), 107.0806 (56), 97.0590 (84), 95.0801 (63), 93.0646 (48).

After solvent evaporation, part of the hexanic extract EsAH (467.0 mg) was fractionated by successive preparative TLC run with $\mathrm{CH}_{2} \mathrm{Cl}_{2}-\mathrm{MeOH}-\mathrm{H}_{2} \mathrm{O}$ (85:15:1). These furnished seven fractions, which were numbered according to their decreasing polarities. Part of the seventh fraction $(174.1 \mathrm{mg}$ ) was fractionated by successive preparative TLC run with $\mathrm{CH}_{2} \mathrm{Cl}_{2}-\mathrm{Hex}$ (9:1). These eleven fractions were numbered according to their decreasing polarities. The fraction 7.11 was purified by preparative TLC continuously run with Hex$\mathrm{Et}_{2} \mathrm{O}(39: 1)$ during $100 \mathrm{~min}$ to afford 2 (4.0 mg) which was analyzed by its NMR and MS spectra data.

\section{Acknowledgments}

The authors are grateful to FAPESP for financial support and for the scholarship awarded to Ana Lúcia T.G. Ruiz. Dr. Maria do Carmo E. do Amaral also thanks CNPq for a research grant.

\section{Supplementary Information}

Supplementary data are available free of charge at http://jbcs.sbq.org.br, as PDF file.

\section{References}

1. Faria, A. D.; MSc. Dissertation, Universidade Estadual de Campinas, Brasil, 1998.

2. Clifford, H. T.; Harbone, J. B.; Phytochemistry 1969, 8, 123; Stevens, K. L.; Merrill, G. B.; J. Agric. Food Chem. 1980, 28, 644; Van Aller, R. T.; Clark, L. R.; Pessoney, G. F.; Rogers, V. A.; Lipids 1983, 18, 617; Miles, D.H.; Tunsuwan, K.; Chittawong, V. J.; J. Agric. Food Chem. 1994, 42, 1561; Quayyum, H. A.; Mallik, A.U.; Orr, D. E.; Lee, P. F.; J. Chem. Ecol. 1999, 25, 221.

3. Amaral, M. C. E.; Faria, A. D.; Magalhães, A. F.; Magalhães, E. G.; Ruiz, A. L. T. G; Phytochem. Anal. 2004, 15, 125; Magalhães, A. F.; Ruiz, A. L. T. G.; Flach, A.; Faria, A. D.; Magalhães, E. G.; Amaral, M. C. E.; Biochem. Syst. Ecol. 2005, 33, 675; Ruiz, A. L. T. G.; Magalhães, E. G.; Magalhães, A. F.; Faria, A. D.; Amaral, M. C. E.; Serrano, D. R.; ZanottiMagalhães, E. M.; Magalhães, L. A.; Braz. J. Pharmacogn. 2005, 15, 98.

4. Olea, R. S. G.; Roque, N. F.; Quim. Nova 1990, 13, 278; Tanaka, R.; Matsunaga. S.; Phytochemistry 1992, 31, 3535.

5. Ageta, H.; Shiojima, K.; Chem. Pharm. Bull. 1990, 38, 347.

6. Budzikiewicz, H.; Wilson, J. M.; Djerassi, C.; J. Am. Chem. Soc. 1963, 85, 3688; Shiojima, K.; Arai, Y.; Masuda, K.; Takase, Y.; Ageta, T.; Ageta, H.; Chem. Pharm. Bull. 1992, 40, 1683.

7. Pereira Jr., O. L.; Wolter Filho, W.; da Rocha, A. F. I.; de Carvalho, M. G.; Braz Filho, R.; Quim. Nova 1990, 13, 247; Hasan, M.; Burdi, D. K.; J. Nat. Prod. 1991, 54, 1444.

8. Magalhães, A. F.; Ruiz, A. L. T. G.; Tozzi A. M. G. A.; Magalhães, E.G.; Phytochemistry 1999, 52, 1681.

Received: September 17, 2004 Published on the web: April 28, 2006

FAPESP helped in meeting the publication costs of this article. 


\section{New Hopane Triterpene from Eleocharis sellowiana (Cyperaceae)}

\section{Ana Lúcia T. G. Ruiz, ${ }^{*, a, b}$ Aderbal F. Magalhães, ${ }^{a}$ Aparecida D. Faria, ${ }^{c}$ Eva G. Magalhães ${ }^{a}$ and Maria do Carmo E. Amaral ${ }^{c}$}

${ }^{a}$ Instituto de Química, Universidade Estadual de Campinas, CP 6154, 13084-862 Campinas - SP, Brazil

${ }^{b}$ Centro Pluridisciplinar de Pesquisas Químicas, Biológicas e Agrárias, Universidade Estadual de Campinas, CP 6171, 13083-970 Campinas - SP, Brazil

${ }^{c}$ Instituto de Biologia, Universidade Estadual de Campinas, CP 6109, 13083-970 Campinas - SP, Brazil

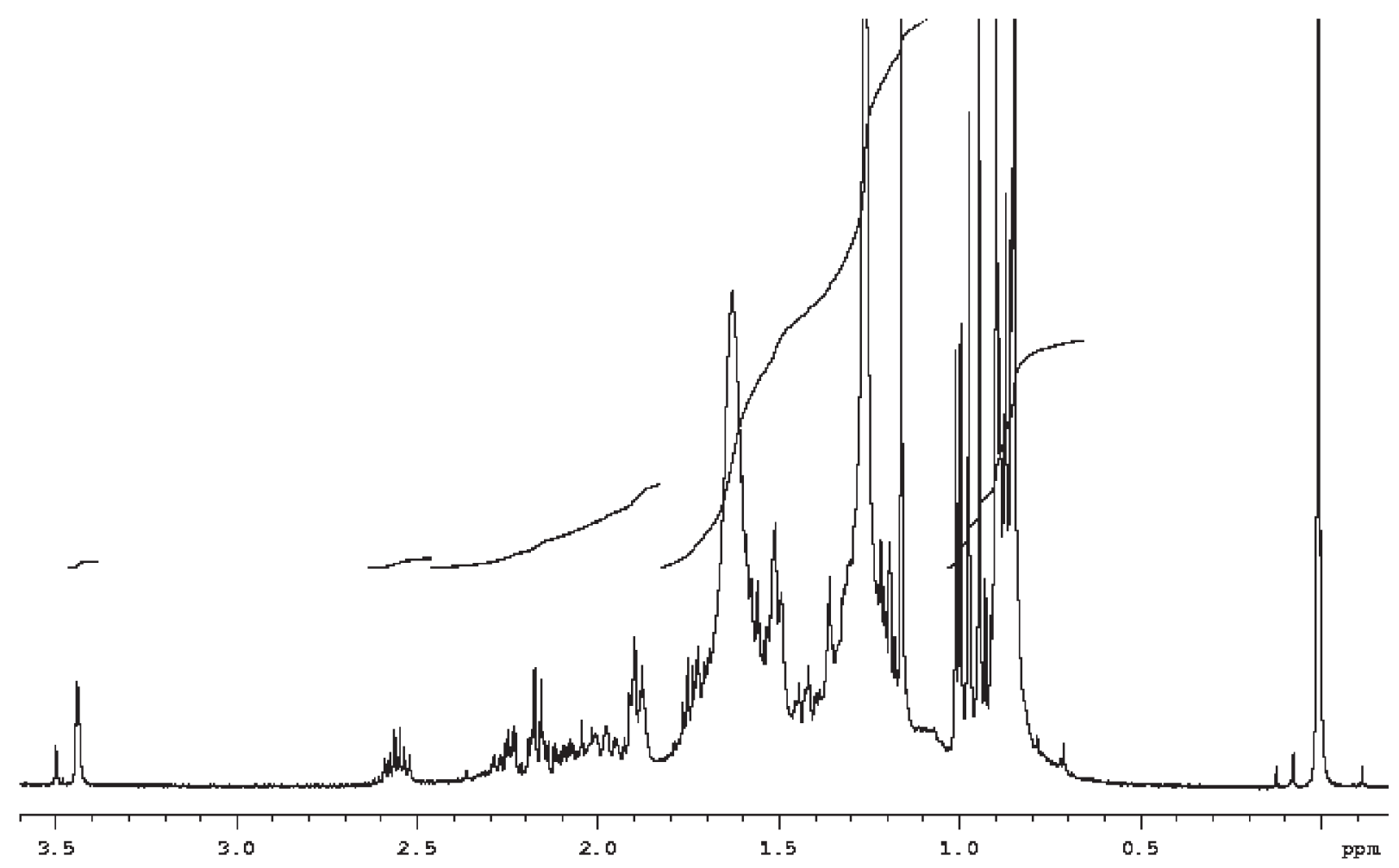

Figure S1. ${ }^{1} \mathrm{H}$ NMR spectrum $\left(500 \mathrm{MHz}, \mathrm{CDCl}_{3} / \mathrm{TMS}\right)$ of $\mathbf{1}$.

* e-mail: aa_ruiz@hotmail.com.br 


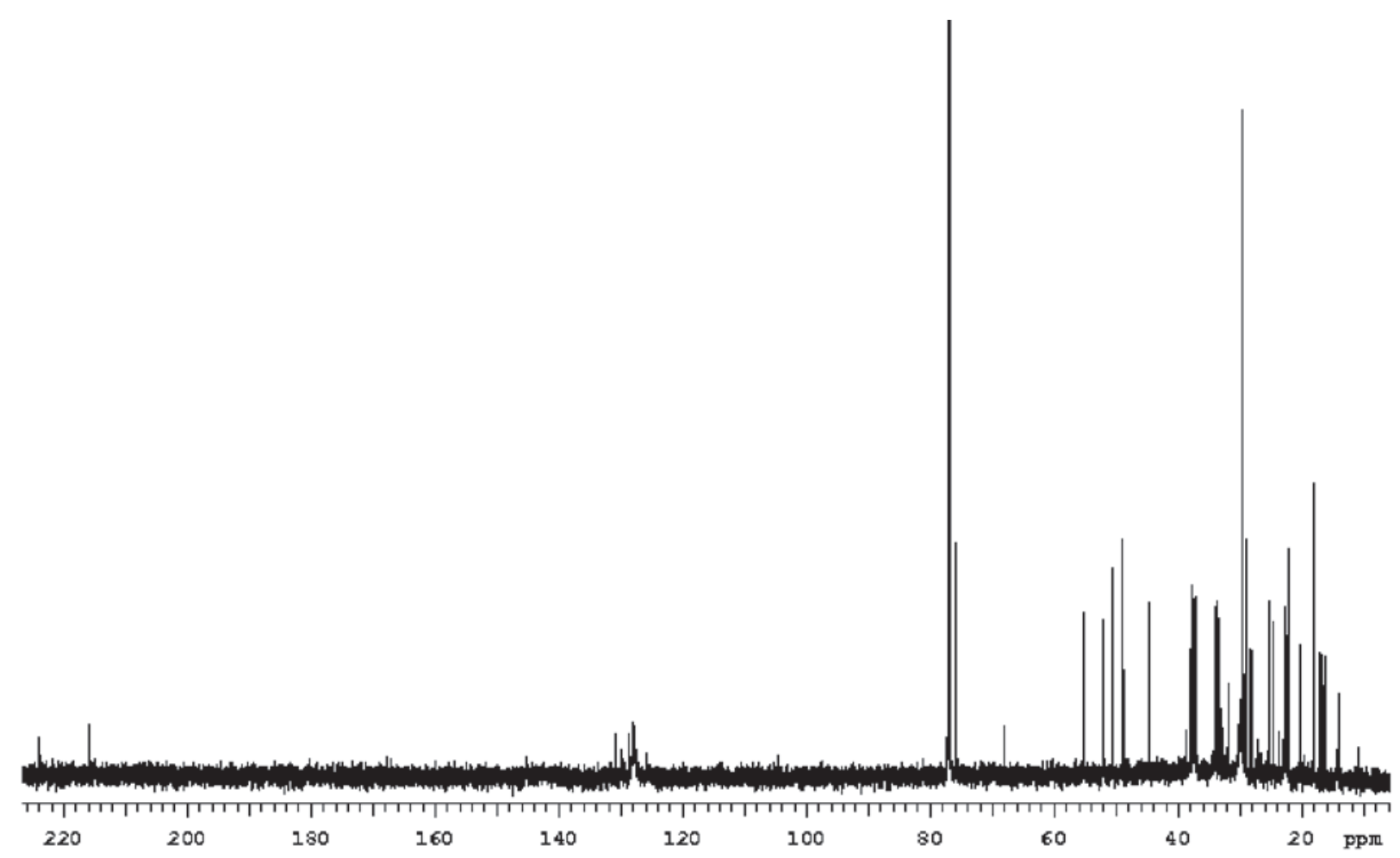

Figure S2. ${ }^{13} \mathrm{C}$ NMR spectrum $\left(125 \mathrm{MHz}, \mathrm{CDCl}_{3} / \mathrm{TMS}\right)$ of $\mathbf{1}$.
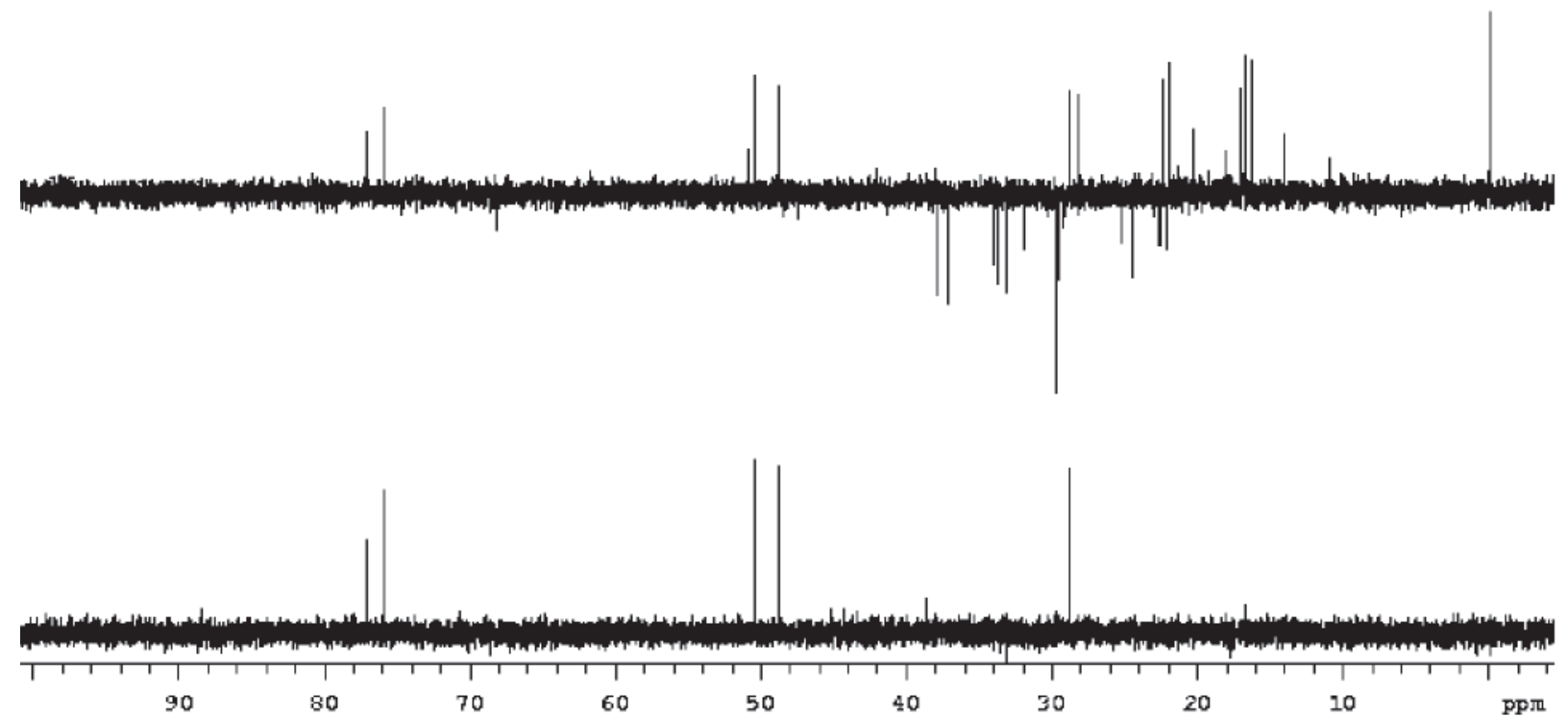

Figure S3. DEPT NMR experiment (125 MHz, $\mathrm{CDCl}_{3} / \mathrm{TMS}$ ) of $\mathbf{1}$. 


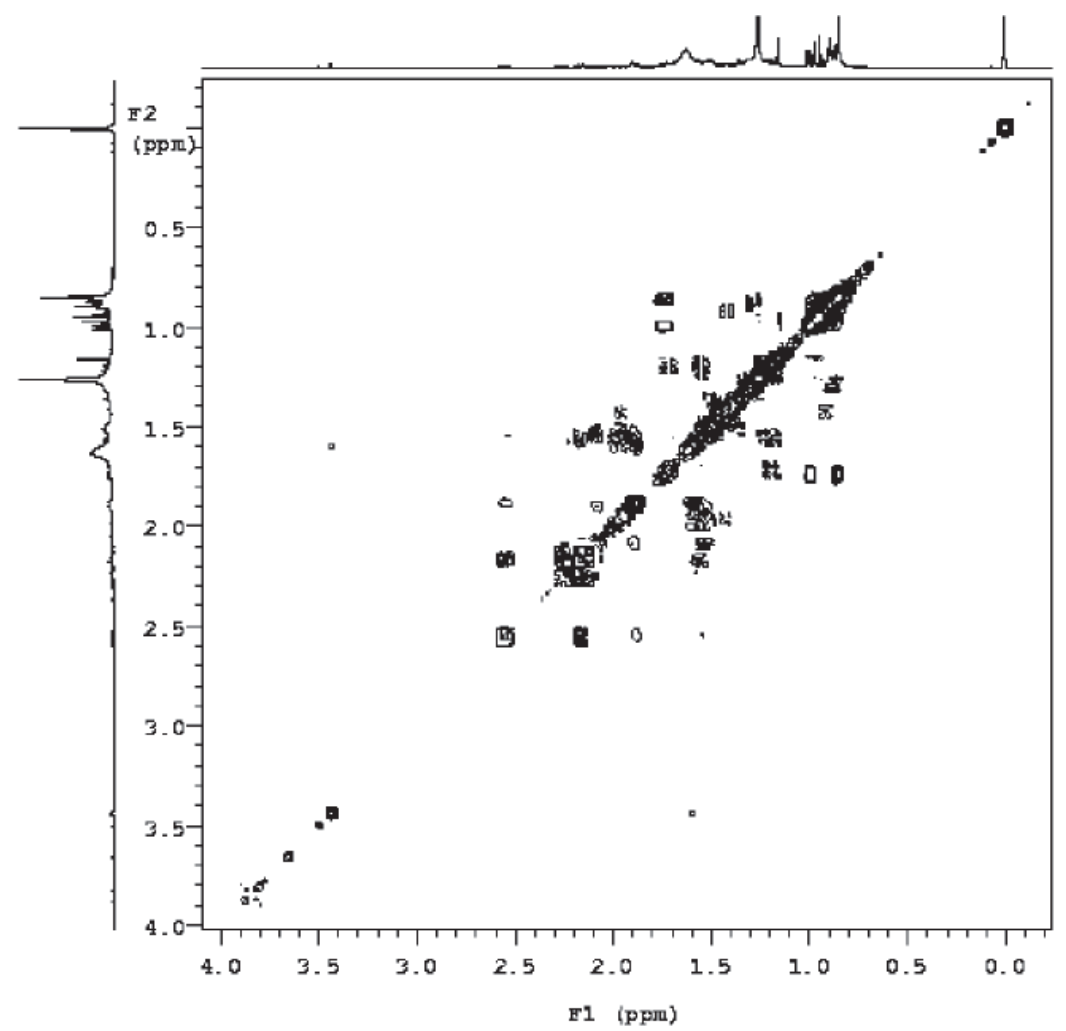

Figure S4. gCOSY NMR experiment (500 MHz, $\left.\mathrm{CDCl}_{3} / \mathrm{TMS}\right)$ of $\mathbf{1}$.

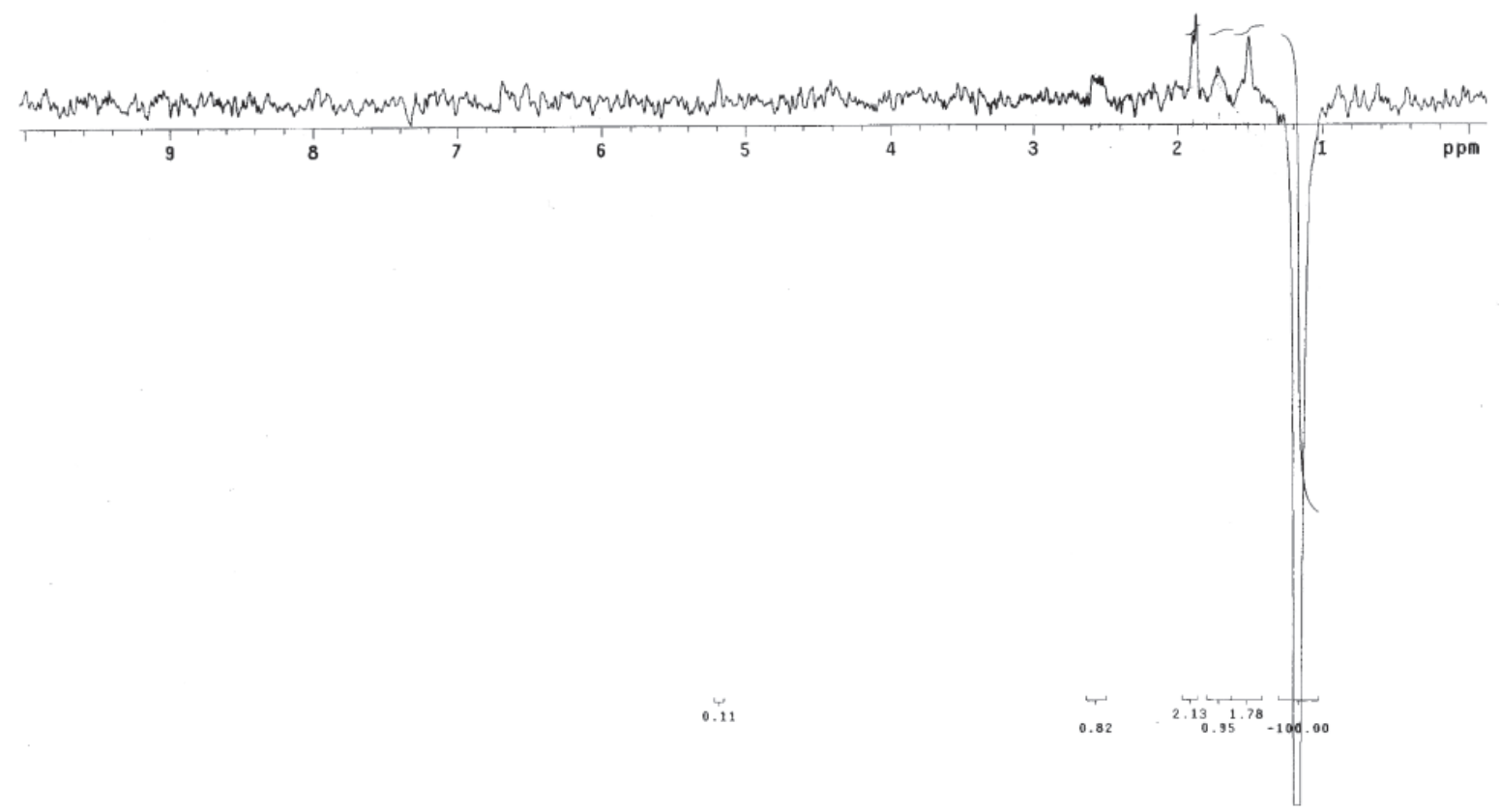

Figure S5. 1D NOESY NMR experiment (500 MHz, CDCl $\left.{ }_{3} / \mathrm{TMS}\right)$ of $\mathbf{1} ; \mathrm{H}-3 \beta\left(\delta_{\mathrm{H}} 3.44\right)$ was irradiated. 


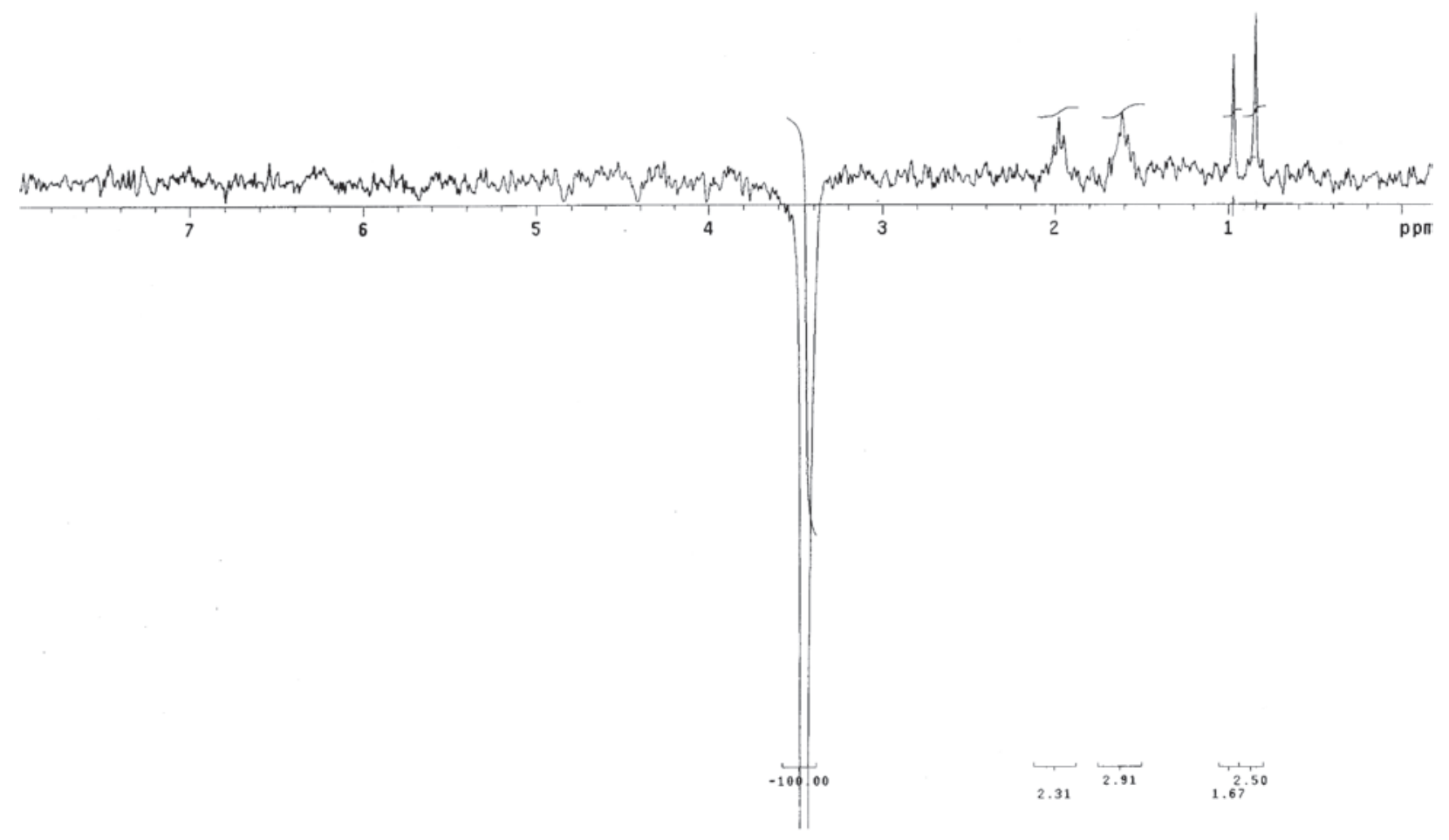

Figure S6. 1D NOESY NMR experiment (500 MHz, CDCl 3 /TMS) of 1; H-27 $\left(\delta_{\mathrm{H}} 1.15\right)$ was irradiated.

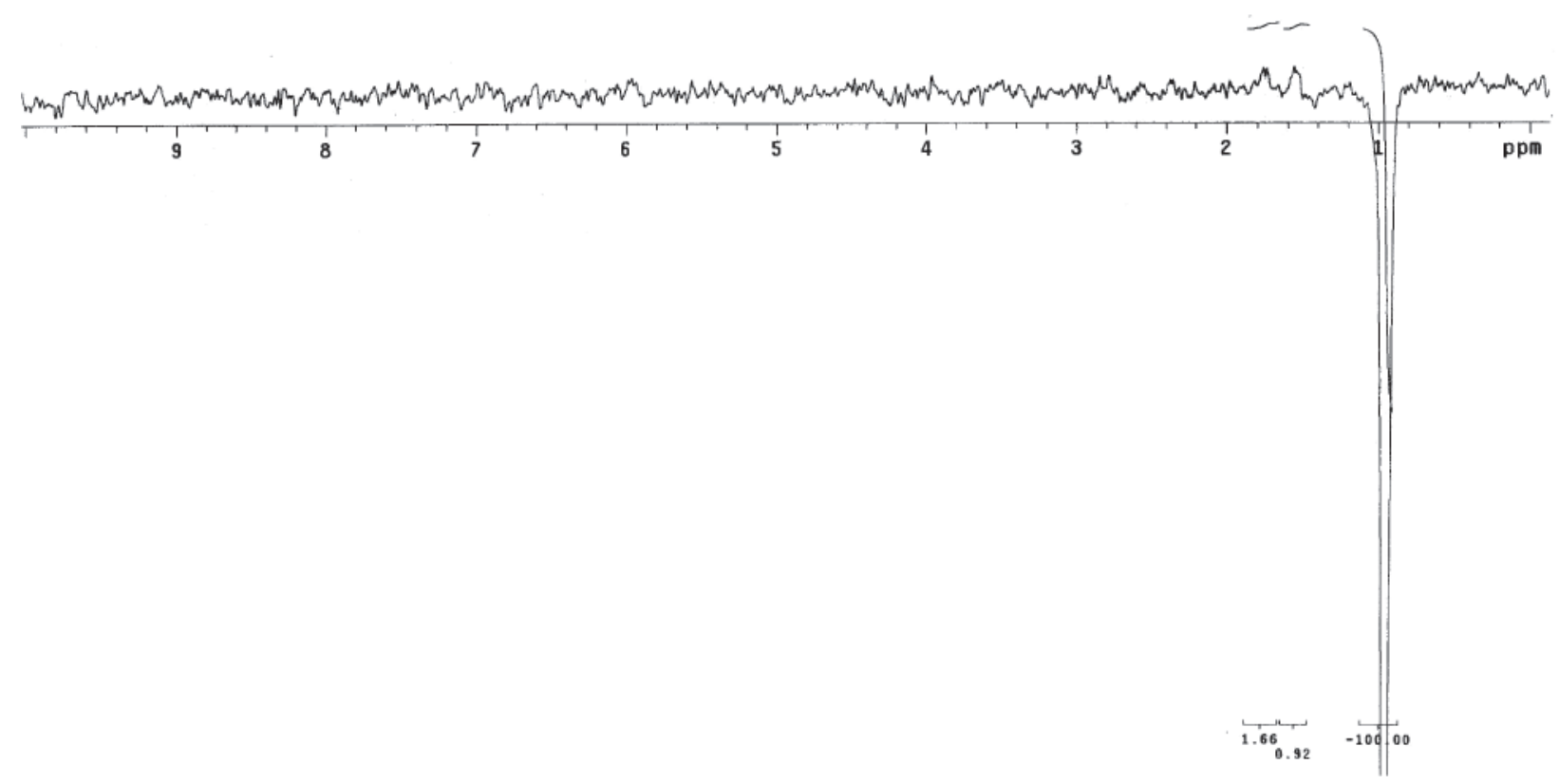

Figure S7. 1D NOESY NMR experiment (500 MHz, $\left.\mathrm{CDCl}_{3} / \mathrm{TMS}\right)$ of $\mathbf{1} ; \mathrm{H}-28\left(\delta_{\mathrm{H}} 0.94\right)$ was irradiated. 
a)

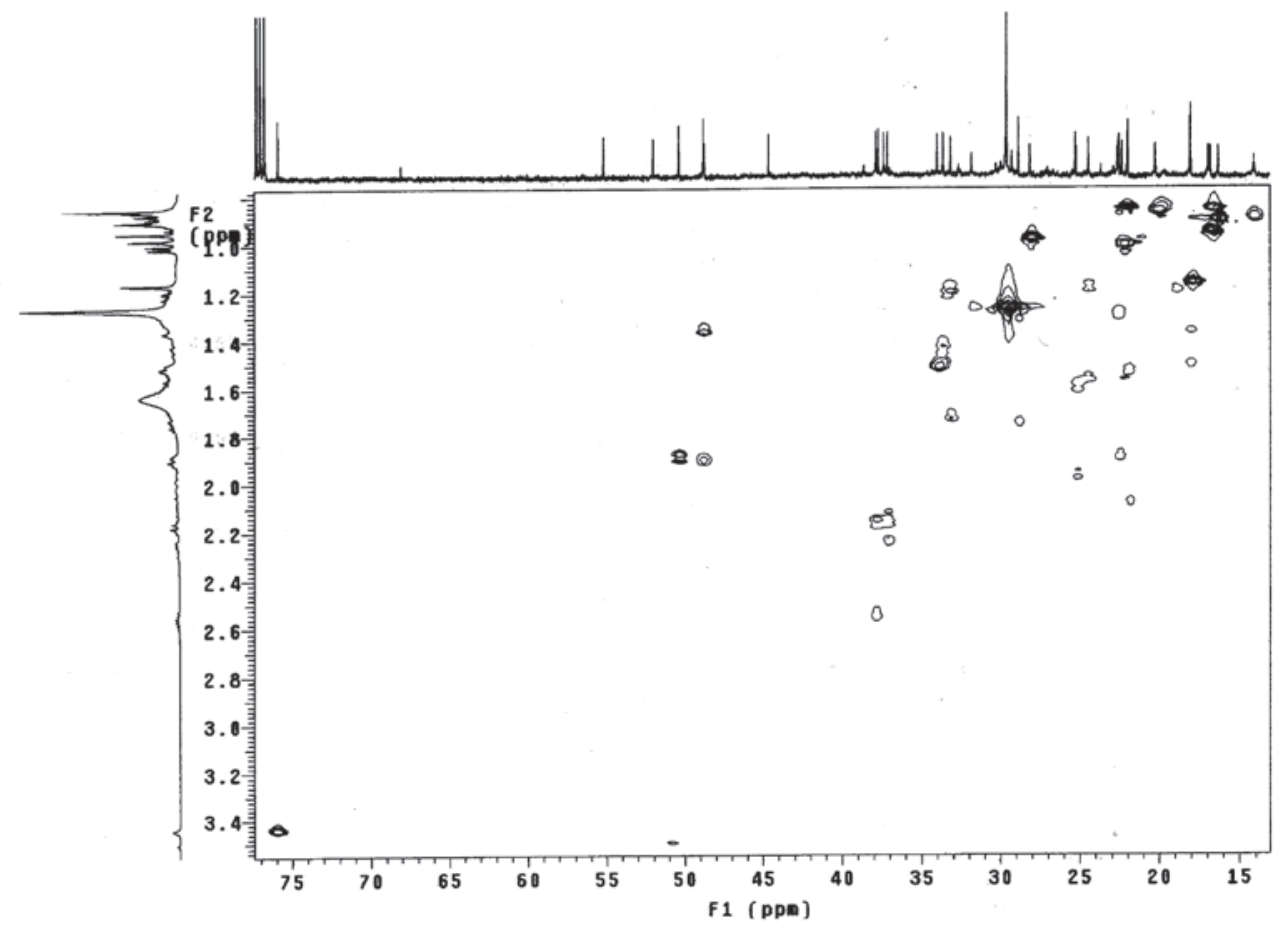

b)

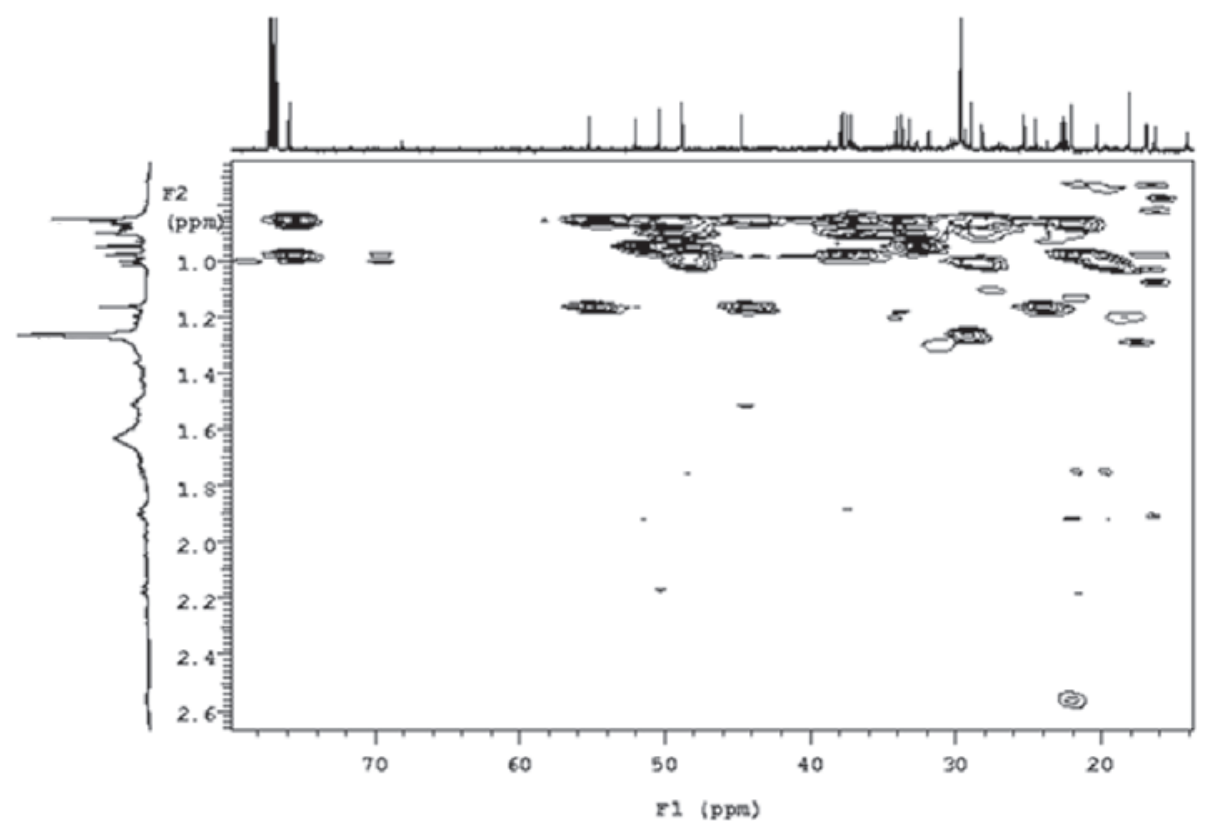

Figure S8. HSQC NMR experiment (a) and HMBC NMR experiment (b) (11 Tesla, $\mathrm{CDCl}_{3} / \mathrm{TMS}$ ) of $\mathbf{1}$. 


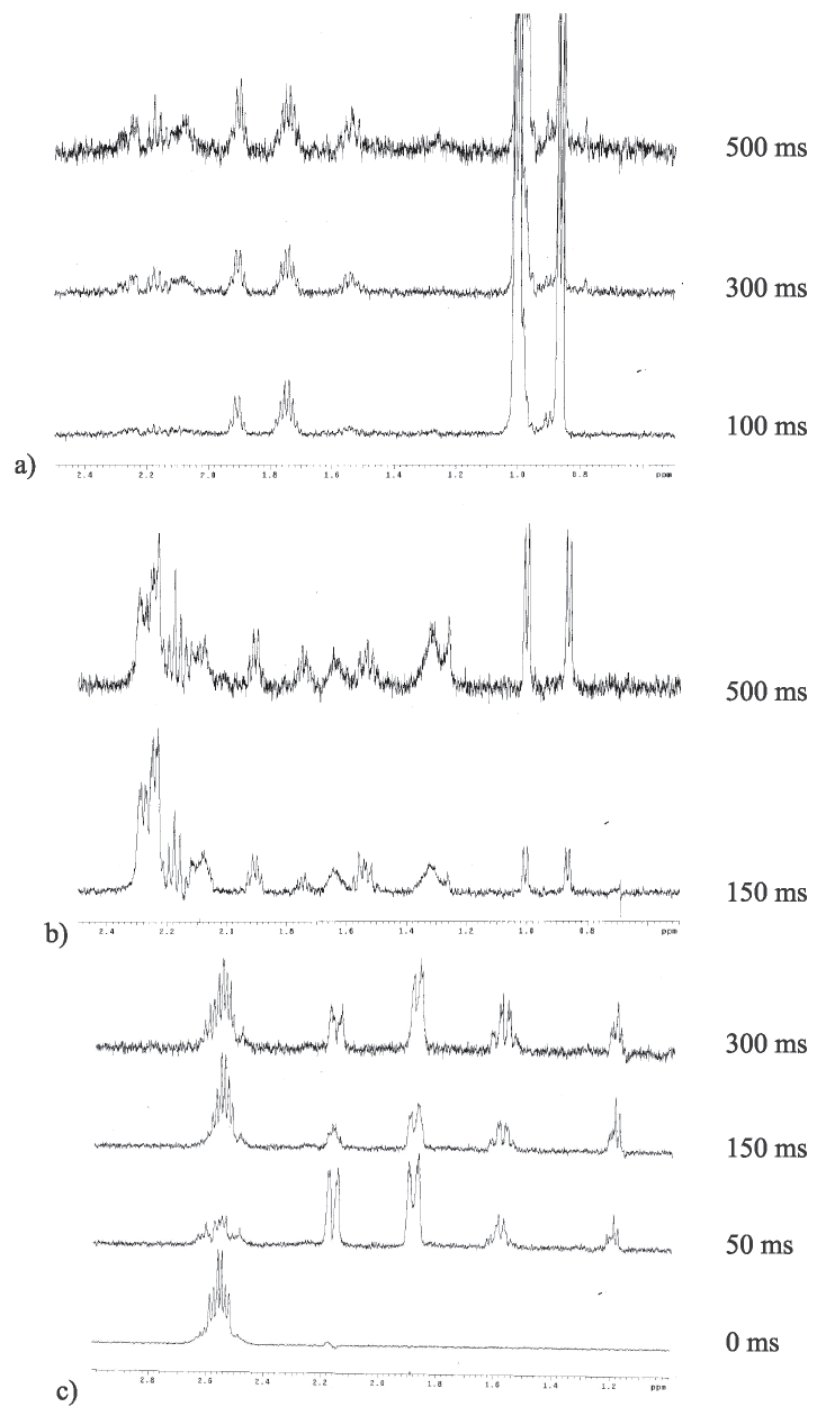

Figure S9. 1D TOCSY experiment (500MHz, $\mathrm{CDCl}_{3} / \mathrm{TMS}$ ) of 1. a) $\mathrm{H}-30$ $\left(\delta_{\mathrm{H}} 1.00\right)$ was irradiated; b) $\mathrm{H}-20\left(\delta_{\mathrm{H}} 2.18\right)$ was irradiated; c) $\mathrm{H}-16$ $\left(\delta_{\mathrm{H}} 2.55\right)$ was irradiated.

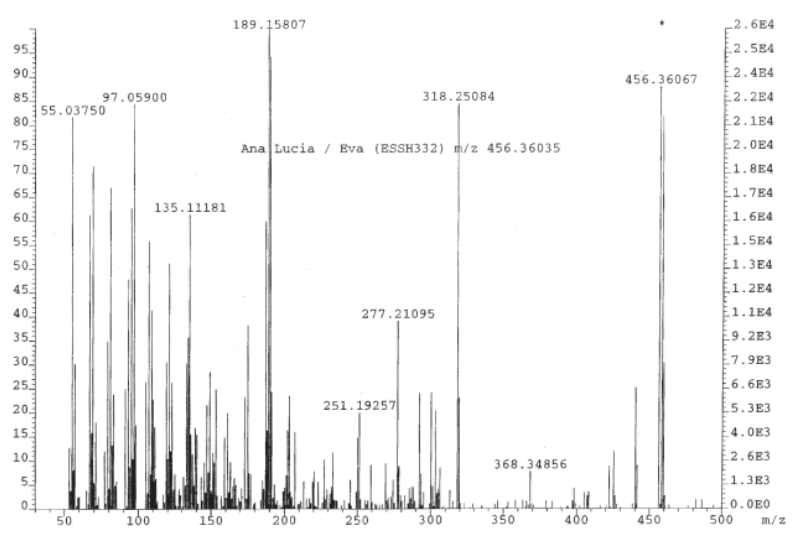

\section{Figure S10. HR-EIMS spectrum of $\mathbf{1}$.}

